\title{
Plant-based traditional foods and beverages of Ramotswa Village, Botswana
}

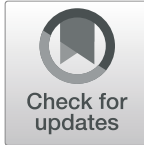

Geremew Bultosa ${ }^{1 *} \mathbb{D}$, Moenyane Molapisi, Nelson Tselaesele², Rosemary Kobue-Lekalake ${ }^{1}$, Gulelat Desse Haki ${ }^{1}$, Shimane Makhabu' ${ }^{3}$ Bonno Sekwati-Monang ${ }^{1}$, Eyassu Seifu ${ }^{1}$ and Gothatamang P. Nthoiwa ${ }^{4}$

\begin{abstract}
Background and objectives: Different communities have various types of edible plants at their nearby ecology from which they process their traditional foods that make the basis of diversified diets for food and nutrition security. Exploration of various ethnic traditional foods knowledge will have an immense contribution for preservation and sustainability of the traditional food system and culture. The objectives of this research were to investigate and document the edible plant type used and description on the processing of plant-based traditional foods/dishes and beverages of the Ramotswa village, Botswana. Majority of the Ramotswa village residents belong to the Balete tribe.
\end{abstract}

Methodology: Questionnaire interviews and focus group discussions (FGD) were used in the documentations of edible plants type, methods involved in the processing, values, challenges, and the seasonal availability.

Results and discussion: There are 50 wild edible plants used and most are available during rainy season. Maize, sorghum, beans, cooking melon, watermelon, and pumpkin are widely used domesticated crops. The edible part of wild plants is utilized in different ways. Some consumed after minor processing and some as cooked, boiled, recipe in traditional dishes, inoculum in fermentation, substrate in traditional beverages, and medicinal plants. Food safety concerns were indicated for few products. High temperature and shortage of rainfall are making some edible plants scarce. For some, preparation takes a long time; and when processing is not properly done, unpleasant odor, bitter taste, and mold growth can result, particularly for traditional beverages. Even though, most traditional foods/dishes and beverages are still consumed and enjoyed by the communities, there are worries that the young generation has limited knowledge and skills to process and utilize them.

Conclusions: Most plant-based traditional foods/dishes consumed are low in sugar and fat, but are wholesome (whole grains, with dietary fibers) with high potential for diet diversification. The documentation provided will help to create awareness for preservation of the traditional foods/dishes and beverage culture, and as a baseline information for further studies for those nutrient and bioactive compound data are not available.

Keywords: Botswana, Bogobe Jwa Ting/Lekatane, Bojalwa Jwa Setswana/lla, Dikgobe, Khadi, Lekatane, Lechotlho, Lengangale, Morogo Wa Dinawa, Mosukujwane tea, Ramotswa, Wild edible plants

\footnotetext{
*Correspondence: Geremewbultosa@gmail.com; gbultosa@buan.ac.bw

'Department of Food Science and Technology, BUAN, P. Bag 0027,

Gaborone, Botswana

Full list of author information is available at the end of the article
}

(c) The Author(s). 2020 Open Access This article is distributed under the terms of the Creative Commons Attribution 4.0 International License (http://creativecommons.org/licenses/by/4.0/), which permits unrestricted use, distribution, and reproduction in any medium, provided you give appropriate credit to the original author(s) and the source, provide a link to the Creative Commons license, and indicate if changes were made. The Creative Commons Public Domain Dedication waiver (http://creativecommons.org/publicdomain/zero/1.0/) applies to the data made available in this article, unless otherwise stated. 


\section{Introduction}

Traditional/indigenous food product(s) are that a given community acquire and process from bio-diverse plant and animal sources available in their ecology in which knowledge and skills are preserved and transmitted by oral or other folklore means. Traditional foods have special place among the communities because of their unique sensory acceptability, cultural heritage, health benefits, religious, and commercial values. For example, the Mediterranean traditional food patterns [1] are highly recognized as healthful because they are associated with the reduction of all causes of mortality [2] and are high in anti-oxidants [2, 3].

The Lancet Commissions review on sustainable food systems [4] recommended to move toward healthy diets derived from whole grains, nuts, fruits, vegetables, and legumes, a low to moderate amount of seafood and poultry, low or no inclusion of red meat, processed meat, added sugar, refined grains, and starchy vegetables to achieve a win-win situation (i.e., sustainable-healthy diets and environment). A review [5] on the documentation of indigenous foods in 11 different countries from 2001 showed that the sustainability of indigenous foods are globally threatened, by factors like an intensive cultivation of limited crops, various anthropogenic activities, urban land policy, and life style changes.

Indigenous food system revival has been given due attention by FAO [6] high-level experts because they are cornerstone for sustainable diets of low environmental impacts [7]. There are more than 14,000 edible plant species globally of which only 150 to 200 species are used from which $60 \%$ of human calories are derived from rice, maize, and wheat [4]. Agro-industrial food system that depends on limited crops has been recognized to cause biodiversity loss, environmental pollution, land degradation, and malnutrition $[4,7,8]$.

A study conducted [9] in Gaborone on cardiovascular disease risk factors reported that a relatively high prevalence of overweight, obesity, and low intake of highdensity lipoprotein (HDL) cholesterol in young adults with a shifting of diets toward high in sugar, refined starches, and meat. Traditional/indigenous food (TIF) consumption in two urban and two rural areas of Botswana were found important for household food security and dietary diversity, even though TIF consumption was declining due to preference for modern foods [10, 11].

In Batswana cuisine, plant-based ingredients used are either harvested from the wild or grown in home gardens and fields of which wild plant contribution are known to be significant [12]. However, information on the types of wild plants and the description on processing of plant-based traditional foods/dishes and beverages used by various ethnic groups within different villages of Botswana are limited. To create awareness on the sustainability of traditional foods of a given community, documentation of traditional food system is important. Such information is used for preservation of traditional food heritage, bio-piracy, biodiversity conservation, unnecessary eradication (clearing), entrepreneurship development, chemical investigation, standard development, wild species domestication, education material to teach in schools, tourism, and food trade fairs. In view of this, in this paper, plant-based foods/dishes and beverages of Ramotswa Village of which majority of the village residents are Balete tribe are reported.

\section{Methodology}

The study was conducted at Ramotswa village $\left(25^{\circ} 13^{\prime} \mathrm{S}\right.$ and 25 40 $\mathrm{E}$, South-East District, $35 \mathrm{~km}$ from Gaborone) (Fig. 1a, b). The majority of the village residents belong to the Balete tribe. A qualitative research approach was followed [13, 14].

A structured questionnaire for face to face interview and questions for FGD were developed through several consultative meetings with a team of scientists (food scientists, sociologist, and botanist). Questions included were edible plants type used, processing, food value, health/medicinal claims, safety and taboos, preservation methods, seasonal availability, challenges, and status on knowledge and culture of indigenous foods. The term "traditional food" and "traditional dish" were defined as those "without recipes" and "with different recipes," respectively. Questionnaire pre-testing was conducted at Bokaa village $\left(24^{\circ} 25^{\prime} 35^{\prime \prime} \mathrm{S}\right.$ and $26^{\circ} 1^{\prime} 0^{\prime \prime}$ E, Kgatleng District, $37 \mathrm{~km}$ northeast of Gaborone).

The Paramount Chief and deputy Chiefs of the Ramotswa village were consulted. They consented to the research objective and FGD schedule and assisted on selection of FGD participants. The criteria used were residents in the village, have full knowledge and skills on traditional foods/dishes and beverages of the village, processing for family consumption and/or for sell, past experience and ability to judge current scenario, knowledge in the culture and language of the communities, both male and female participation, and age between 40 and 87 years. The FGD was conducted involving 14 participants by an experienced sociologist. When consensus on a particular issue was reached among FGD participants, information generated was captured on flip chart by the facilitator and two rapporteurs on note books. An audio decoder was also used.

The interviews were conducted by trained enumerator, a resident of Ramotswa village. Vernacular language and wherever possible English language were used, and the scientific names on the list of edible plants were generated by a Botanist Dr. Shimane Makhabu at BUAN, Botswana. The data from 25 questionnaires were 


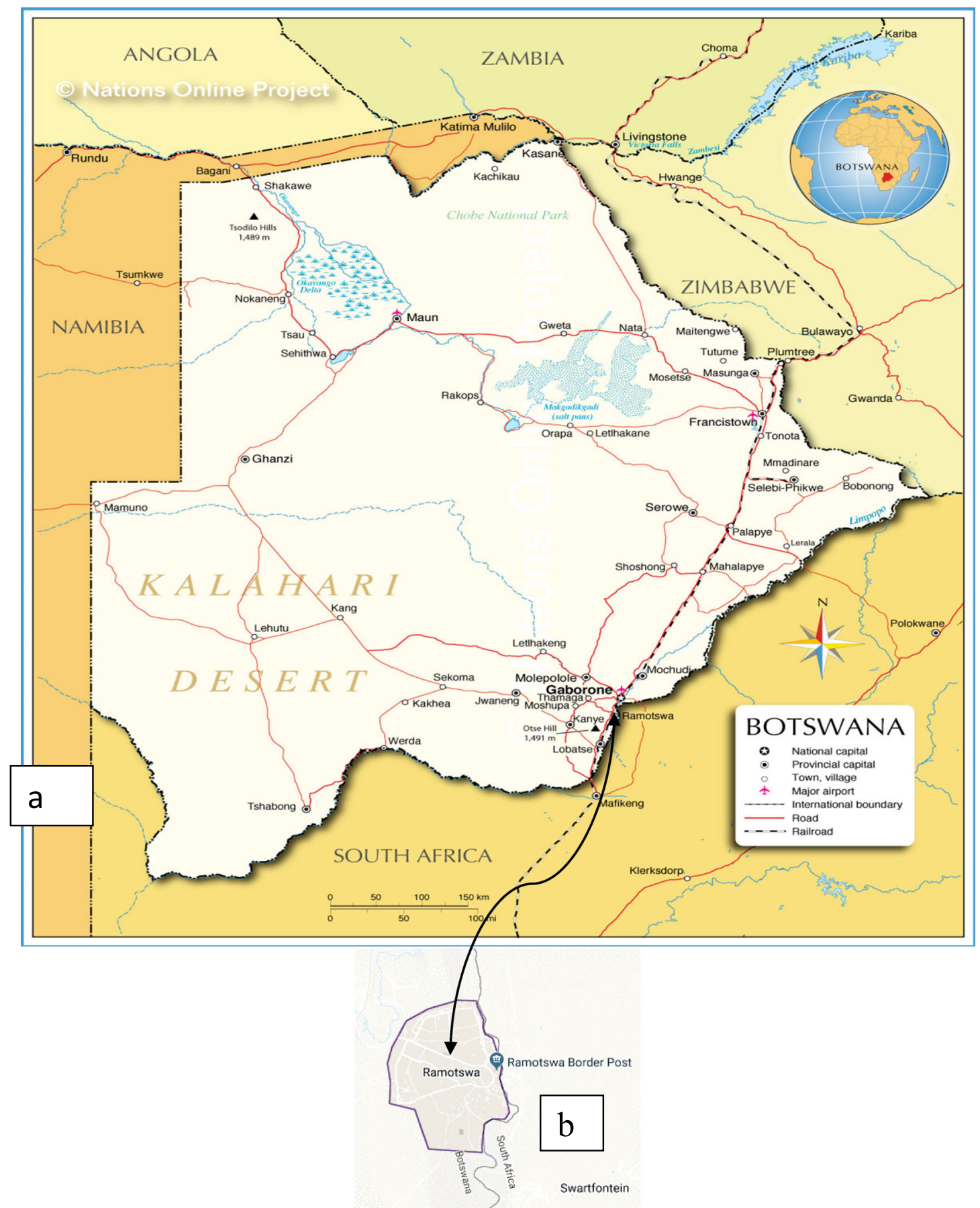

Fig. 1 Maps of a Botswana and b Botswana's South East District where Ramotswa village is located at about $35 \mathrm{~km}$ south from Gaborone

decoded in a spreadsheet of Microsoft Excel, 2013, and responses were extracted and reconciled information with FGD are reported.

\section{Results and discussions}

The participant demographic characteristics are shown in Table 1. All participants were from Balete tribe,
Christians. Majority of them were subsistence farmers and household food processors.

\section{Wild food plants}

There are 50 wild edible plants used in the study area (Table 2). For most fruits/pulp, in some cases like morula (Scleroccaria birrea), the seeds/nuts are also used. For motlopi (Boscia albitrunca) and mogakangwaga 
Table 1 Demographic characteristics of participants from Ramotswa village, Botswana

\begin{tabular}{|c|c|c|c|}
\hline \multicolumn{2}{|l|}{ Demography } & \multirow{2}{*}{$\frac{\text { Interview }}{13}$} & \multirow{2}{*}{$\frac{F G D}{10}$} \\
\hline Gender & Male & & \\
\hline & Female & 12 & 4 \\
\hline \multirow[t]{6}{*}{ Age (years) } & $21-30$ & 6 & 0 \\
\hline & $31-40$ & 8 & 0 \\
\hline & $41-50$ & 2 & 0 \\
\hline & $51-60$ & 0 & 1 \\
\hline & $61-70$ & 5 & 5 \\
\hline & $>70$ & 4 & 8 \\
\hline \multirow[t]{7}{*}{ Education } & Cannot read or write & 5 & 4 \\
\hline & Primary education & 4 & 6 \\
\hline & Secondary education & 5 & 1 \\
\hline & Certificate & 2 & 1 \\
\hline & Diploma & 5 & 0 \\
\hline & Bachelor's degree & 4 & 1 \\
\hline & Postgraduate degree & 0 & 1 \\
\hline \multirow[t]{11}{*}{ Occupation } & Subsistence farmer/house hold food processor & 11 & 4 \\
\hline & Kgosana (deputy chief) & 0 & 9 \\
\hline & Large scale food processor & 2 & 0 \\
\hline & Mechanics & 1 & 0 \\
\hline & Internship & 3 & 0 \\
\hline & Unemployed & 3 & 1 \\
\hline & Teacher & 1 & 0 \\
\hline & Human resource & 1 & 0 \\
\hline & Policeman & 1 & 0 \\
\hline & Carpenter & 1 & 0 \\
\hline & Graduate & 1 & 0 \\
\hline
\end{tabular}

(Trochomeria debilis), fruits and roots/tubers of the same plant are used. Some are used as leafy vegetables (Table 2). For mokgalo (Ziziphus mucronata), its fruit pulp, leaves, roots, bark, and seeds are used. Mokgalo seeds are ground and eaten as powder, and leaves' paste is used to heal wounds, sores, and boils, while its roots are boiled and the juice is used to relief pain. Fruits of morula and moretlwa (Grewia flava) are used in the traditional beverages. Some leaves such as mosukujane (Lippia scaberrima), kgomodimetsing (Myrothamnus flabellifolius), lengana (Artemisia afra), seswagadi (Jatropha zeyheri), rammola, and moritelatshwene are used for tea-like beverages. The fruits of motlopi are used in the traditional beverages, and its roots for making a coffee type beverage. Fruit pulp of mmupudu (Mimops zeyheri) can be compacted and dried for preservation. Mogwana (Grewia bicolor) fruits are used to flavor traditional beverage khadi. Khusubele (Withania spomnifera) is used as a relish. Water is extracted from the roots of leruswa (Stomatostemma monteiroae). The fruits of morobe (Ehretia $s p$.) were indicated to cause constipation if consumed in large amounts. No taboo indicated for wild edible plants. Availability of most wild edible plants is limited after rains. Most of them were described as perishable, whereas few as semiperishable and durable (Table 2). The study indicates that with availability of water, there is domestication potential. However, to make them available during off rainy season, development of appropriate food preservation technologies are required. For some wild edible plants, market potential was high and very high, however, for majority was poor (Table 2).

\section{Wild plants for foods and medicinal use}

The economic value, potential for food and nutrition security of Botswana edible wild plants [15-17], wild vegetables [18], and medicinal importance [19] for some indicated in this paper were described. Morula 


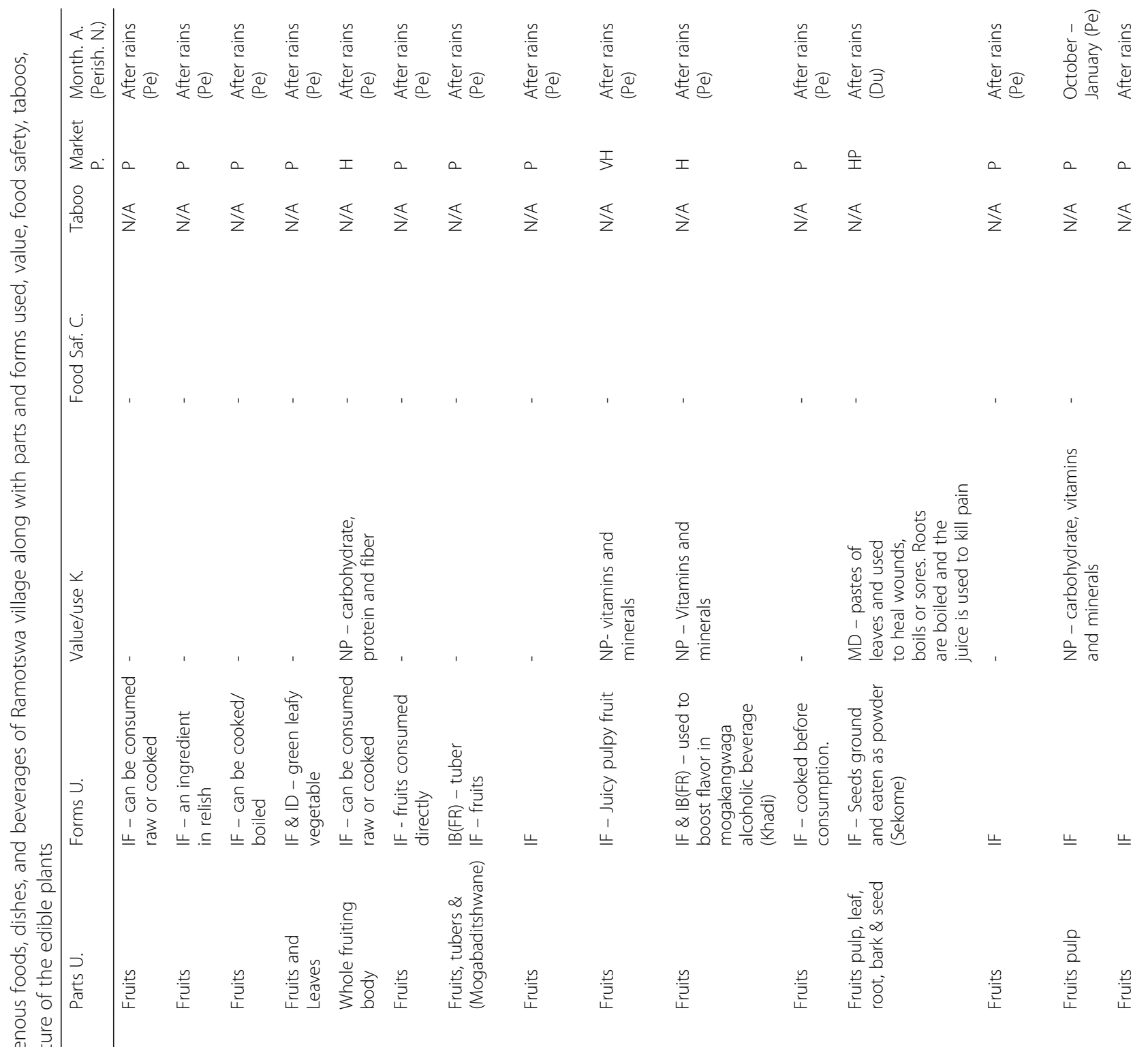

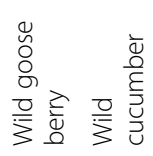

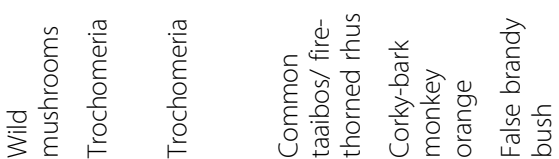

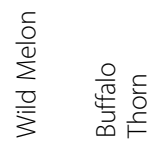

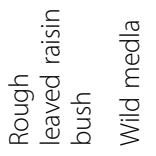

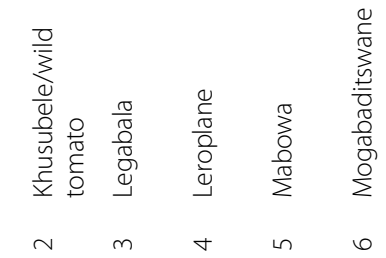
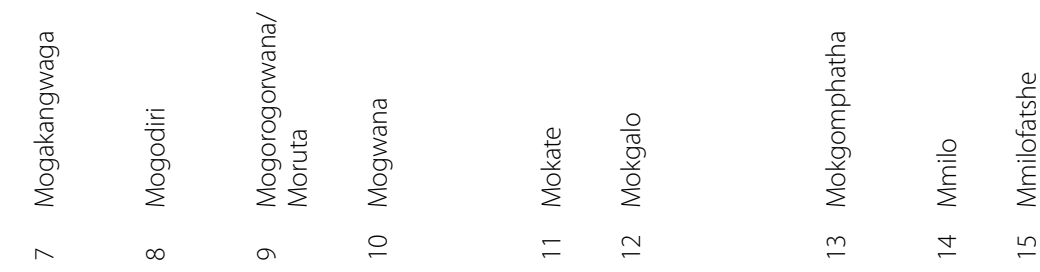


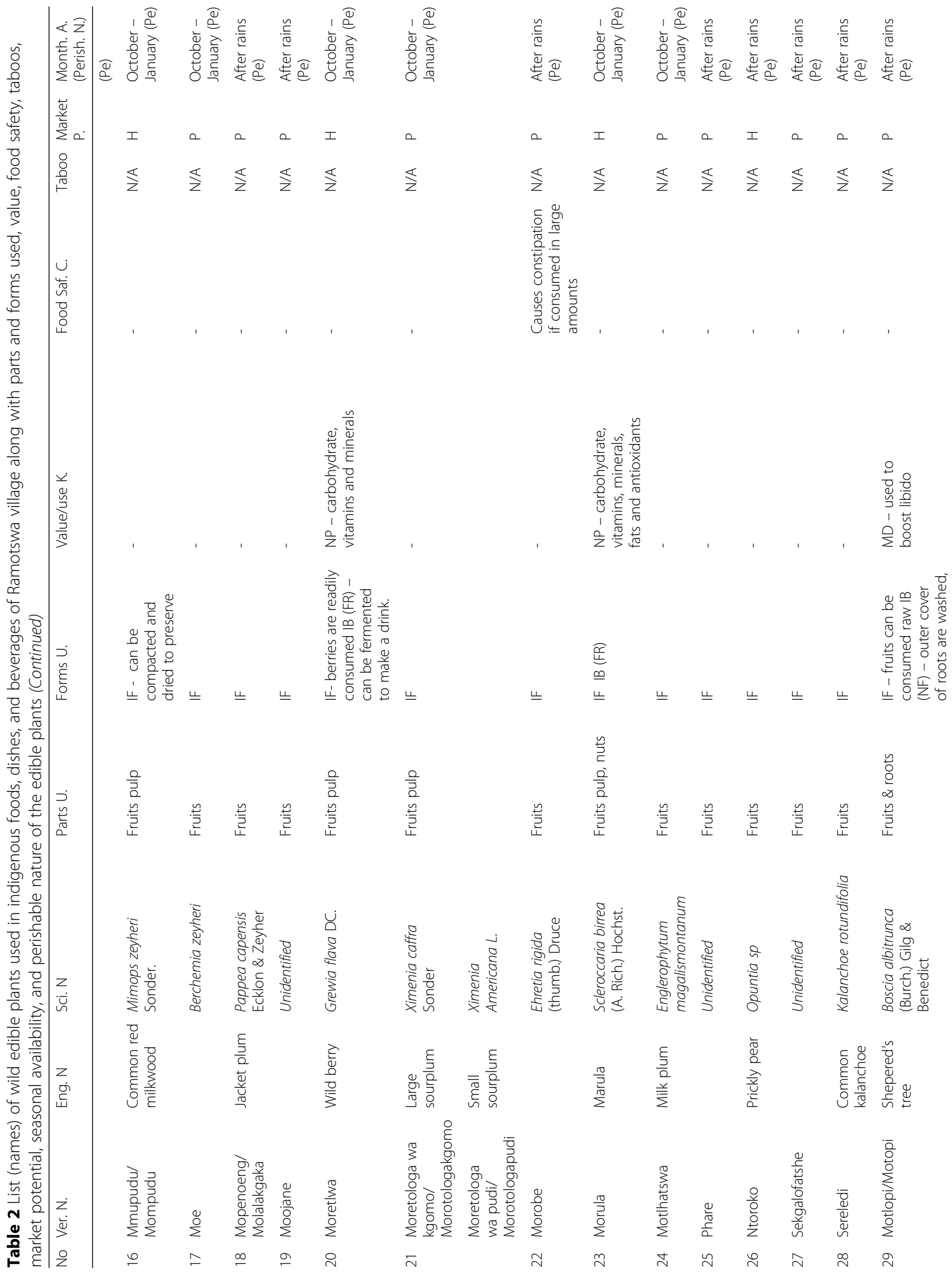




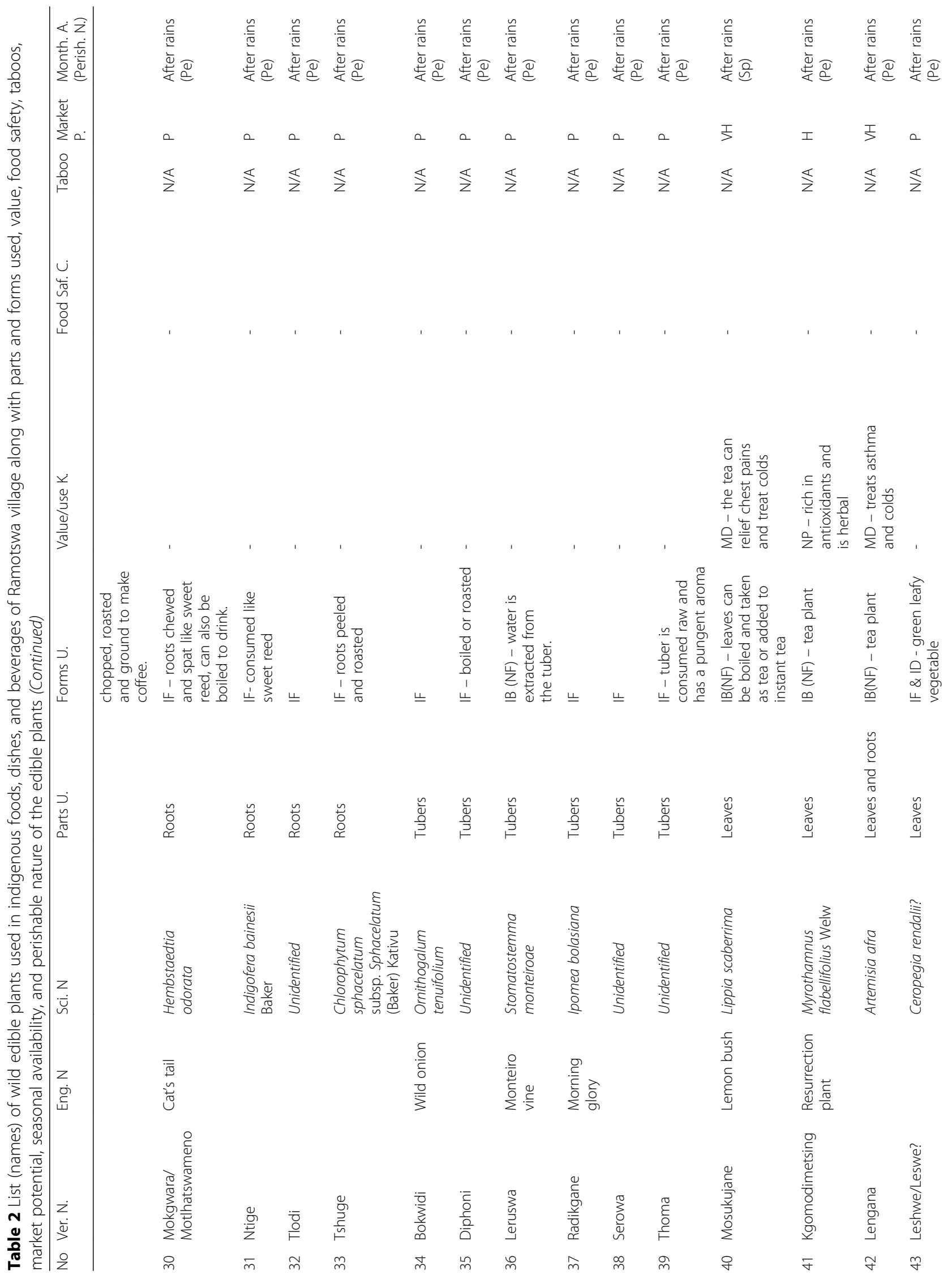




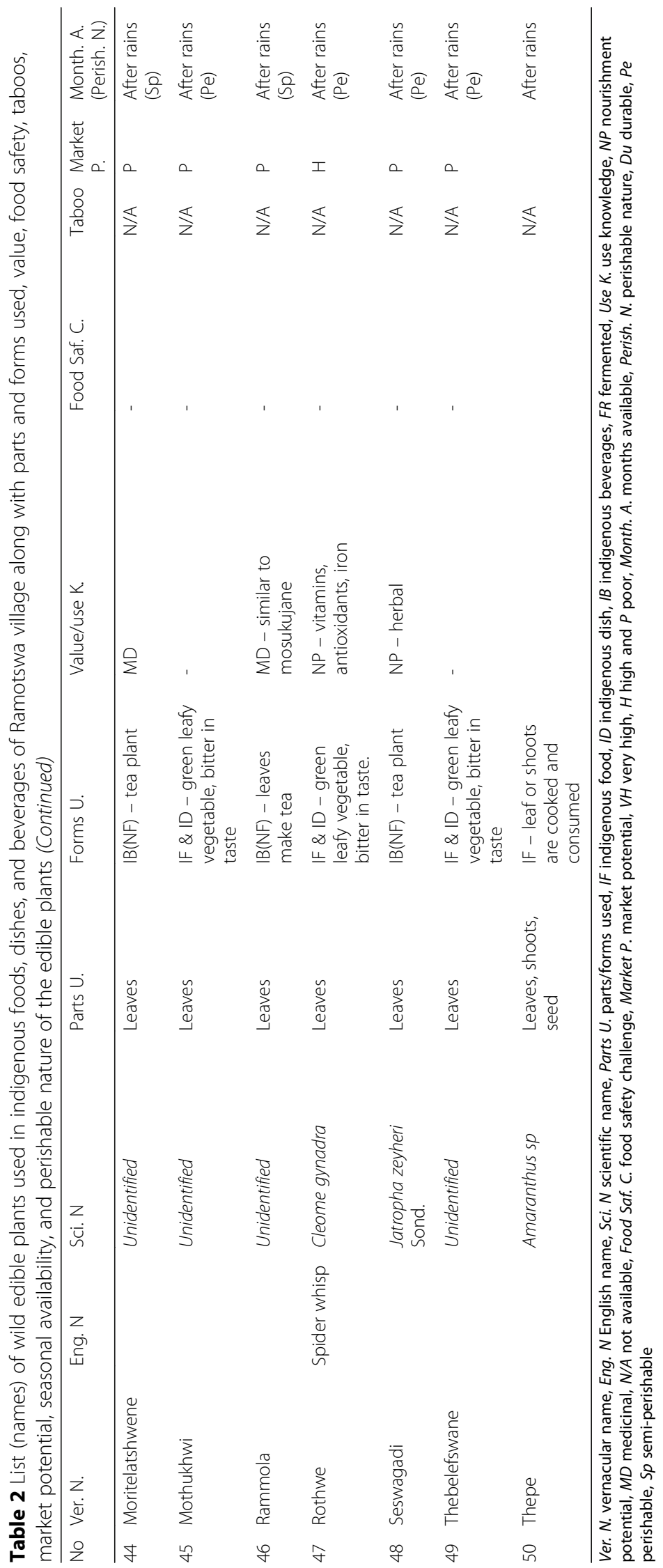


and mmilo (Vanguera infausta) were valuable sources of vitamin $\mathrm{C}$, fibers, and minerals ( $\mathrm{K}$ and $\mathrm{Mg}$ ) [20]. Mokgalo roots were reported to have a strong antioxidant activity $\left(\mathrm{IC}_{50}, 2.5 \mathrm{mg} / \mathrm{mL}\right)$ [21], and the bark to treat some diseases [22]. Motlopi is eaten either raw or cooked and can be concentrated to make a syrup and porridge, and its unripe fruits are used to treat epilepsy [23]. Mmupudu has potential for production of jam, jelly, and dried products [24]; its roots are used to treat syphilis, stomach ache, and gynecological infections and leaves for diabetes mellitus management [25]; and flavonoids were indicated as major bioactive compounds [26]. Ximenia caffra and mmupudu seed oils were reported to have anti-proliferative effect on human colon adenocarcinoma (Caco-2), human embryonic kidney (HEK-293) cells [27], and women breast cancer cell lines [28]. Both seed oils were rich in oleic acid: $59.4 \%$ and $55.7 \%$, respectively [27]. Lengana is one of the most commonly used herbal medicines in the southern African region because of its monoterpenoids and sesquiterpenes [29] and described as tea plant. Its leaves and roots were indicated to treat asthma and colds with very high demand.

\section{Domesticated food plants}

There are 13 domesticated edible plants used (Table 3). Sorghum, maize, and pearl millet are used in traditional foods/dishes; sorghum and maize in

Table 3 List (names) of domesticated edible plants used in indigenous foods, dishes, and beverages of Ramotswa village along with parts used, value, food safety, taboos, market potential, seasonal availability, and perishable nature

\begin{tabular}{|c|c|c|c|c|c|c|c|c|c|c|}
\hline No & Ver. N. & Eng. $\mathrm{N}$ & Sci. N & Parts U. & Forms U. & Value/Use K. & $\begin{array}{l}\text { Food } \\
\text { Saf. C. }\end{array}$ & Taboo & $\begin{array}{l}\text { Market } \\
\text { P. }\end{array}$ & $\begin{array}{l}\text { Month. A. } \\
\text { (Perish. N.) }\end{array}$ \\
\hline 1 & Mabele & Sorghum & $\begin{array}{l}\text { Sorghum } \\
\text { bicolor } \mathrm{L} \text {. }\end{array}$ & Grains & $I F, I D \& \mid B(F R)$ & $\begin{array}{l}\mathrm{NP} \text { - fiber, carbohydrate, } \\
\text { vitamins and N/minerals }\end{array}$ & - & $\mathrm{N} / \mathrm{A}$ & $\mathrm{VH}$ & $\begin{array}{l}\text { January - } \\
\text { April (Du) }\end{array}$ \\
\hline 2 & Mmidi & Maize & Zea mays $\mathrm{L}$. & Grains & $I F, I D \& \mid B(F R)$ & $\begin{array}{l}\mathrm{NP} \text { - fiber, carbohydrate, } \\
\text { vitamins and minerals }\end{array}$ & - & N/A & $\mathrm{VH}$ & $\begin{array}{l}\text { January - } \\
\text { April (Du) }\end{array}$ \\
\hline 3 & Lebelebele & Pearl millet & $\begin{array}{l}\text { Pennisetum } \\
\text { glaucum (L.) } \\
\text { R. Br. }\end{array}$ & Grains & $I F, I D$ & - & - & N/A & $P$ & $\begin{array}{l}\text { January - } \\
\text { April (Du) }\end{array}$ \\
\hline 4 & Dinawa & $\begin{array}{l}\text { Common } \\
\text { beans }\end{array}$ & $\begin{array}{l}\text { Phaseolus } \\
\text { vulgaris L. }\end{array}$ & $\begin{array}{l}\text { Pulses/ } \\
\text { seeds }\end{array}$ & $\mathbb{I F}, \mathrm{ID}$ & $\begin{array}{l}\mathrm{NP} \text { - proteins, fiber, } \\
\text { vitamins and minerals }\end{array}$ & - & N/A & $\mathrm{VH}$ & $\begin{array}{l}\text { January - } \\
\text { April (Du) }\end{array}$ \\
\hline 5 & Ditloo & Jugo beans & $\begin{array}{l}\text { Vigna } \\
\text { subterranean } \\
\text { (L.) Verdc }\end{array}$ & $\begin{array}{l}\text { Pulse/ } \\
\text { seeds }\end{array}$ & $\mathrm{IF}, \mathrm{ID}$ & $\begin{array}{l}\mathrm{NP} \text { - proteins, fiber, } \\
\text { vitamins and minerals }\end{array}$ & - & N/A & $\mathrm{H}$ & $\begin{array}{l}\text { January - } \\
\text { April (Du) }\end{array}$ \\
\hline 6 & Letlhodi & Mung bean & $\begin{array}{l}\text { Vigna radiata }(\mathrm{L}) \\
\mathrm{R} \text {. Wilczek }\end{array}$ & $\begin{array}{l}\text { Pulse/ } \\
\text { seeds }\end{array}$ & $I F, I D$ & $\begin{array}{l}\text { NP - protein, vitamins } \\
\text { and minerals }\end{array}$ & - & N/A & $\mathrm{H}$ & $\begin{array}{l}\text { January - } \\
\text { April (Du) }\end{array}$ \\
\hline 7 & $\begin{array}{l}\text { Manoko/ } \\
\text { matonkomane }\end{array}$ & Groundnuts & $\begin{array}{l}\text { Arachis } \\
\text { hypogaea L. }\end{array}$ & Nuts & $\begin{array}{l}\text { IF- nuts are readily } \\
\text { consumed. Also } \\
\text { cooked with other } \\
\text { grains to complement } \\
\text { protein source }\end{array}$ & $\begin{array}{l}\mathrm{NP} \text { - rich in protein } \\
\text { and fats }\end{array}$ & - & N/A & $\mathrm{VH}$ & $\begin{array}{l}\text { January - } \\
\text { April (Du) }\end{array}$ \\
\hline 8 & Sonobolomo & Sunflower & $\begin{array}{l}\text { Hellianthus } \\
\text { annus L. }\end{array}$ & Grains & $\begin{array}{l}\text { IF - Roasted and } \\
\text { eaten as a snack }\end{array}$ & $\begin{array}{l}\text { NP - high in oil. Also } \\
\text { has some minerals }\end{array}$ & - & N/A & $\mathrm{VH}$ & $\begin{array}{l}\text { January - } \\
\text { April (Du) }\end{array}$ \\
\hline 9 & Lephutshe & Pumpkin & $\begin{array}{l}\text { Cucurbita } \\
\text { pepo L. }\end{array}$ & Pulp & IF & $\begin{array}{l}\mathrm{NP} \text { - carbohydrate, } \\
\text { vitamins, minerals } \\
\text { and fiber }\end{array}$ & - & $\mathrm{N} / \mathrm{A}$ & $\mathrm{H}$ & $\begin{array}{l}\text { January - } \\
\text { April (Sp) }\end{array}$ \\
\hline 10 & Magapu & Watermelon & $\begin{array}{l}\text { Citrullus lanatus } \\
\text { (Thunb.) var. } \\
\text { lanatus }\end{array}$ & $\begin{array}{l}\text { Pulp \& } \\
\text { seeds }\end{array}$ & $I F \& \mid B(F R)$ & $\begin{array}{l}\mathrm{NP} \text { - carbohydrate, } \\
\text { vitamins and minerals }\end{array}$ & - & $\mathrm{N} / \mathrm{A}$ & $\mathrm{VH}$ & $\begin{array}{l}\text { January - } \\
\text { April (Pe) }\end{array}$ \\
\hline 11 & Makgomane & Squash & & Fruit & IF & $\begin{array}{l}\mathrm{NP} \text { - vitamins and } \\
\text { minerals }\end{array}$ & - & $\mathrm{N} / \mathrm{A}$ & $\mathrm{H}$ & $\begin{array}{l}\text { January - } \\
\text { April (Du) }\end{array}$ \\
\hline 12 & $\begin{array}{l}\text { Marotse/ } \\
\text { makatane/ } \\
\text { maowane }\end{array}$ & Melon & $\begin{array}{l}\text { Citrullus lanatus } \\
\text { var. citroides (L. } \\
\text { H. Bailey) Mansf. }\end{array}$ & $\begin{array}{l}\text { Pulp, } \\
\text { seeds, } \\
\text { rind }\end{array}$ & $\mathrm{IF}, \mathrm{ID}$ & $\begin{array}{l}\mathrm{NP} \text { - rich in vitamins } \\
\text { and antioxidants }\end{array}$ & - & N/A & $\mathrm{VH}$ & $\begin{array}{l}\text { January - } \\
\text { April (Pe) }\end{array}$ \\
\hline 13 & Ntšhê & $\begin{array}{l}\text { Sweet reed } \\
\text { (sweet } \\
\text { sorghum) }\end{array}$ & $\begin{array}{l}\text { Sorghum bicolor } \\
\text { (L.) Moench }\end{array}$ & $\begin{array}{l}\text { Stem } \\
\text { reed }\end{array}$ & IF & $\begin{array}{l}\text { NP - sugars, } \\
\text { carbohydrates, fiber }\end{array}$ & - & N/A & $\mathrm{VH}$ & $\begin{array}{l}\text { January - } \\
\text { April (Pe) }\end{array}$ \\
\hline
\end{tabular}

Ver. $N$. vernacular name, Eng. $N$ English name, Sci. $N$ scientific name, Parts $U$. parts/forms used, IF indigenous food, $I D$ indigenous dish, $I B$ indigenous beverages, $F R$ fermented, Use K. use knowledge, NP nourishment potential, Food Saf. C. food safety challenge, N/A not available, $V H$ very high, $H$ high and $P$ poor, Month. $A$. months available, Perish. $N$. perishable nature, $D u$ durable, $P$ e perishable, $S p$ semi-perishable 
fermented beverages. Among pulses, common beans, Jugo beans and Mung beans, are consumed in traditional foods/dishes. Ground nuts are consumed as snacks, oil sources, or cooked with other recipes. Sunflower is consumed as a roasted whole snack. Watermelon (Citrullus lanatus (Thunb.) var. lanatus) pulp and seeds are consumed in traditional foods. The melon (Citrullus lanatus var. citroides (L. H. Bailey) Mansf.) pulp, rind, and seed are consumed in the traditional foods and dishes. Pumpkin pulp and makgomane (squash like) fruits are used in traditional foods. The edible plant parts are used as sources of fiber, carbohydrates, vitamins, and minerals. Some also indicated to have health-promoting properties probably because of their anti-oxidant potential. No taboos on the domesticated plants were reported. The market potential for most domesticated edible plants were very high and high, but pearl millet was indicated poor (Table 3). The market potential for pearl millet is probably low due to its high-fat content prone to rancidity.

\section{Indigenous foods}

Borekhu (gums from trees and bushes of genera Vachellia and Senegalia))

Borekhu is consumed as a snack right there after harvest extract, especially from Vachellia tortilis. The extract is also found in mogonono (Terminalia sericea). The product is available from September to November.

\section{Bogobe Jwa Ting (fermented sorghum porridge)}

Cleaned sorghum grains milled into flour or decorticated sorghum grain flour is mixed with warm water $(1: 2, \mathrm{w} / \mathrm{v})$ and left to ferment for 2 days. To speed-up fermentation, potatoes are cut and added into the mixture. Potatoes supply starch and sugar as substrate and may also contribute to fermenting microorganisms, in which case fermentation only takes 1 day. The fermented paste is called "ting." The fermented paste is cooked to porridge in a boiling water for about $15 \mathrm{~min}$ while whisking to avoid lumps. The product is usually consumed with sugar, milk, madila (sour milk) or other relishes, and supply fiber and proteins. It may cause heart burn to some individuals. Ting is available throughout the year.

\section{Mosokwane (unfermented sorghum porridge)}

The cooking method for mosokwane is similar to that for ting, and it can be consumed with milk, madila, soup, meat, or other relishes.

\section{Ditloo (Jugo beans) and Lethodi (mung bean)}

Both beans are cooked, salt, and edible oil may be added for taste. The product is said to supply proteins, fiber, and carbohydrates and is available from January to June.
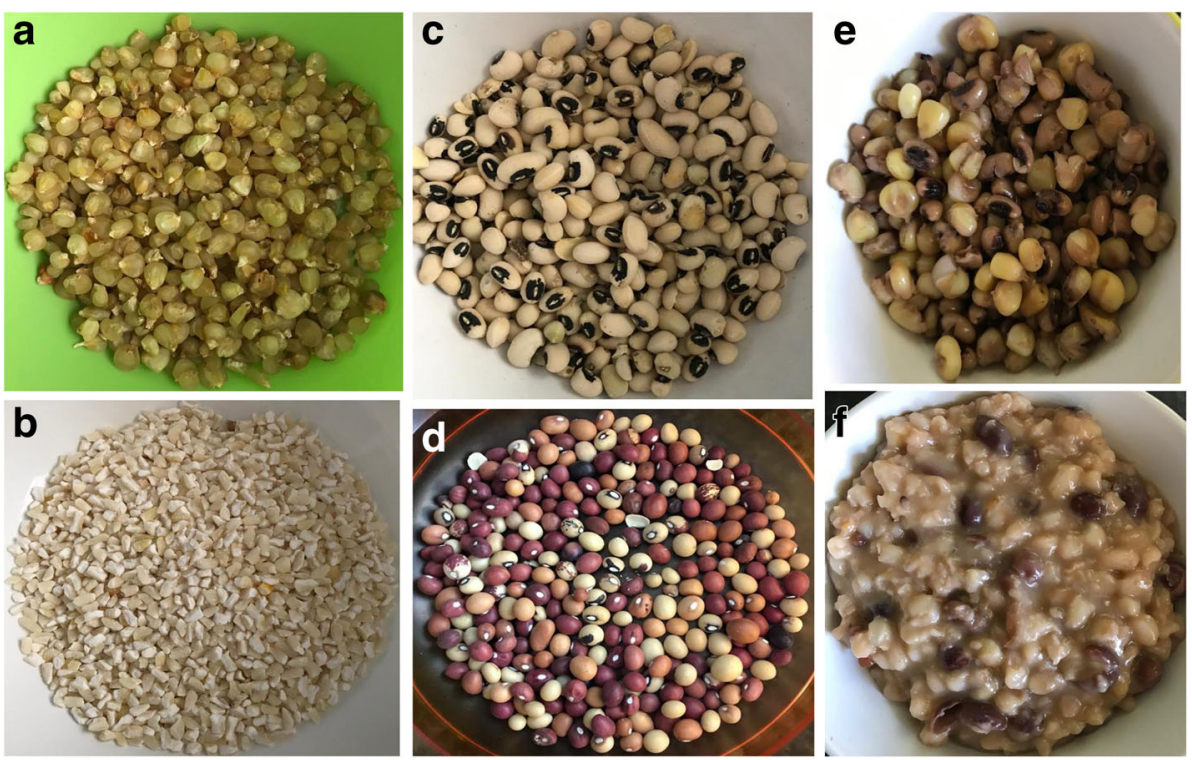

Fig. 2 a Lechotho (maize mealies-fresh maize grains at around physiological maturity is cooked with its sheath while on its cob and then dried), ingredient for processing of Dikgobe. b Samp (Setampa-decorticated and cracked maize grains), ingredient for processing of Dikgobe. c Blackeye cowpeas, pulse ingredient for processing of Dikgobe. $\mathbf{d}$ Bambara ground nut, pulse ingredient for processing of Dikgobe. e Dikgobe tsa lechotlho (blackeye cowpea and lechotlho-cooked). f Dikgobe tsa setampa (decorticated maize and Bambara ground nut-cooked) 


\section{Lechot/ho (Letshot/ho, Mpsapsa)}

Lechotlho is processed by cooking physiologically ripe maize grains in water with its sheath on its cobs (Fig. 2a). The cooked maize is cooled, sun dried, and stored until needed. Lechotlho is a parboiled maize and is whole grain. Besides, being whole grain, it is possible that bioactive compounds can also diffuse into the cooked grain from the maize sheath while cooking as for parboiled rice. The dried product can be stored for 2 to 3 months. After re-cooking, lechotlho is eaten as snack or cooked with beans to make dikgobe (Fig. 2d). Lechotlho may cause constipation if taken in large amounts and is available from April to May.

\section{Lebutho (cooked maize)}

Ripe whole maize grains on its cob without sheath is cooked, and the grain is removed from its cob and dried. The dried grain can be stored for about 12 months. After re-cooking, lebutho is eaten as snack or cooked with beans to make dikgobe. Lebutho provides energy and may cause constipation in some individuals and is available from December to May.

\section{Lengangale}

Lengangale is processed from lerotse/lekatane (Fig. 3a) rind. Melon rind is sliced into stripes and sun dried for about 3 days. If not properly dried, it can develop mold. Dried lerotse (lengangale) can be stored at room temperature for about 1 year. Lengangale is cooked and served and is available from January to June.

\section{Lekatane/makatane/marotse}

Lekatane (melon, an orange-fleshed type of melon used for cooking only) is cooked in water for $30 \mathrm{~min}$, and salt may be added for taste and can be served with milk or sour milk (kgodu ya lerotse/lekatane) (Fig. 3b). Lekatane is said rich in calcium and helps to develop strong bones, supplies fiber, and may cause bloating. Lekatane is available from March to May.

\section{Lekgomane/makgomane/maraka}

Makgomane (whole with its seed) is cut in half and washed and cooked for about $30 \mathrm{~min}$. Salt may be added for taste and then can be served plain or with milk. Lekgomane is reported to give energy, fiber, and calcium and to prevent constipation. Lekgomane may cause uneasiness (bloating) in some individuals and is available from March to May.

\section{Leswabi (dried sweet reed, ntšhê)}

Ntšhê stalk is harvested, outer green layer peeled off, and sun dried for 2 to 3 days and consumed as snack. Leswabi gives energy, because of its sugar, but can cause tooth decay. Leswabi is stored in a cool dry place for 6 months and is available from March to May.
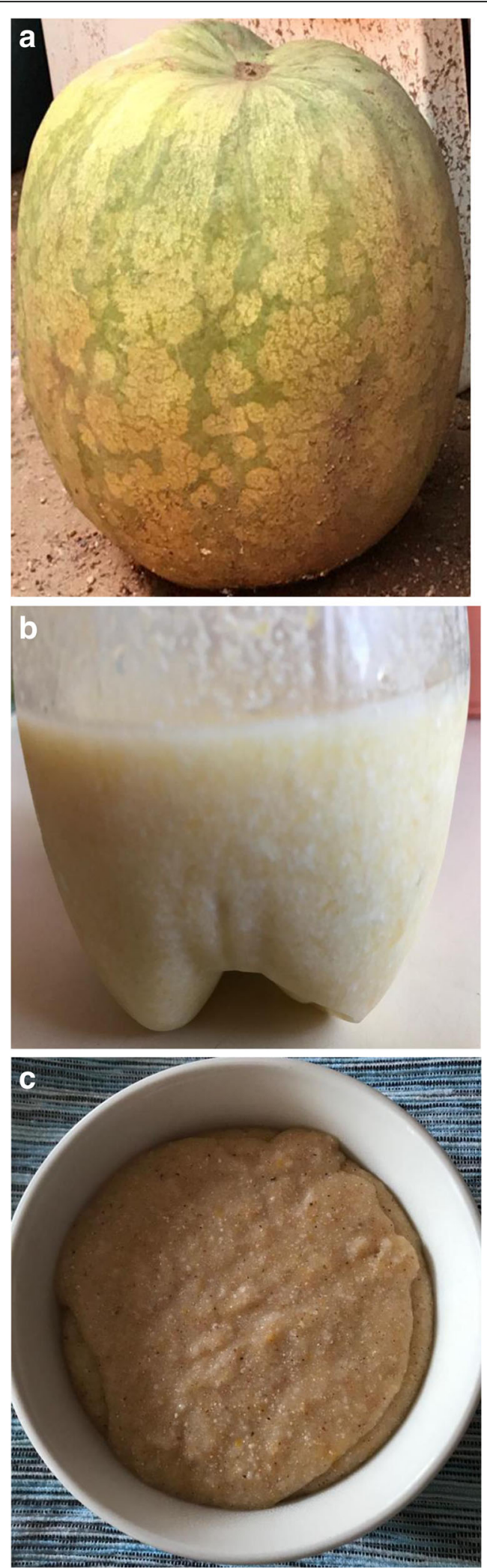

Fig. 3 a Melon (Lekatane/Lerotse). b Kgodu ya lerotse/lekatane (melon and sour milk mixture). c Bogobe jwa lerotse/lekatane (sorghum melon porridge) 


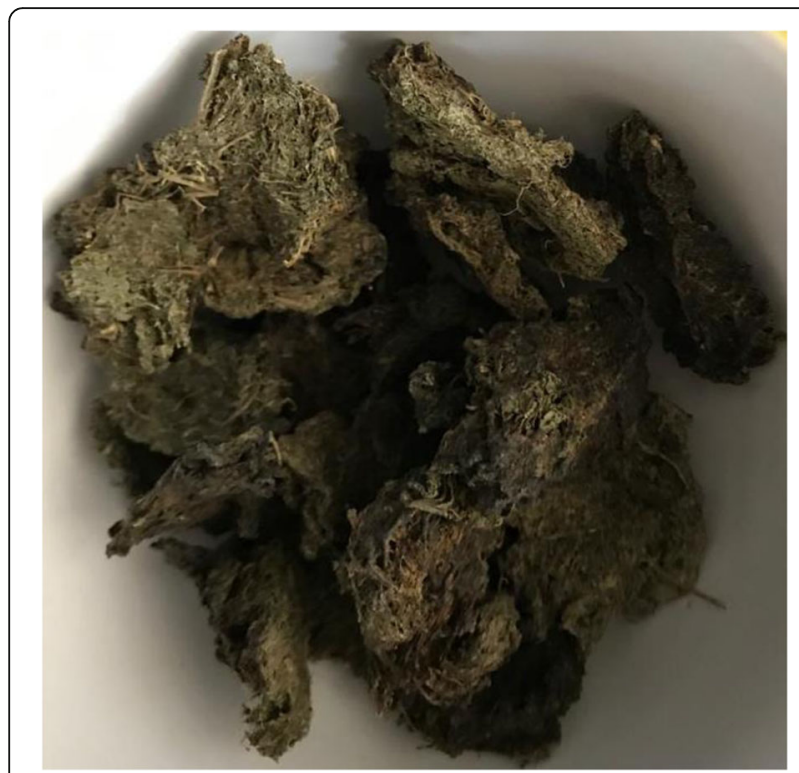

Fig. 4 Morogo wa dinawa (cooked and dried bean/cowpea leaves)

\section{Morogo Wa Dinawa (cooked and dried pulse leaves)}

The cowpea leaves are cooked in water for 1 to $2 \mathrm{~h}$ and pounded until become soft. After then are spread in an open sack to sun dry. The dried product can be stored for about 1 year (Fig. 4). To prepare, morogo wa dinawa, the dried leaves are re-constituted in water, drained, and then cooked. Salt, onion, tomato, and edible oil may be added. The product is high in fiber and is indicated may cause diarrhea and heart burn in some individuals. The product is available from April to June.

\section{Indigenous dishes}

Bogobe Jwa Lekatane/lerotse (melon porridge) (typical example Fig. 3c)

There are three methods of processing from sorghum and melon.

\begin{tabular}{ll}
\hline Kgodu preparation method & Sorghum flour/paste \\
\hline $\begin{array}{l}\text { a. Melon is washed and sliced, and } \\
\text { seeds and rinds are removed; }\end{array}$ \\
cooked and fermented to make & \\
Kgodu & \\
b. Melon is washed and sliced, and & Fermented sorghum paste \\
seeds and rinds are removed; & \\
cooked to make Kgodu & \\
c. Melon is washed and sliced, & Unfermented sorghum flour and \\
and seeds and rinds are removed; & sour milk can be also added during \\
cooked to make Kgodu (sour milk & cooking \\
may be added) & \\
\hline
\end{tabular}

Method a: The pulp is cooked until smooth and cooled, and milk is added. The mixture is stored in an airtight container to ferment. The product is called "kgodu" and is refrigerated until needed. Kgodu is boiled and sorghum flour is added to make a thin or thick porridge. Method b: the melon pulp is cooked until smooth to make "kgodu" to which ting (fermented sorghum paste) is added and further cooked for about 30 min into thin or thick porridge. Method c: the melon pulp is cooked until smooth to make "kgodu" to which sorghum flour is added to make thin or thick porridge. The sour milk may be mixed with kgodu or added during porridge cooking. The porridge is cooked for about $30 \mathrm{~min}$. The product is reported to be rich in vitamins and proteins and is available from March to April when melons are in season.

\section{Dikgobe \\ Dikgobe formulation}

\begin{tabular}{|c|c|c|}
\hline Name & Maize grain & Legumes (beans or peas) \\
\hline $\begin{array}{l}\text { Dikgobe tsa lechotlho } \\
\text { (Fig. 2e) }\end{array}$ & Lechotlho & $\begin{array}{l}\text { Letlhodi, cowpea (Fig. 2c) or } \\
\text { Bambara ground nut }\end{array}$ \\
\hline Dikgobe tsa lebutho & Lebutho & $\begin{array}{l}\text { Letlhodi, cowpea, or Bambara } \\
\text { ground nut (Fig. } 2 \text { d). }\end{array}$ \\
\hline Dikgobe tsa mmidi & $\begin{array}{l}\text { Dried whole } \\
\text { grain maize }\end{array}$ & $\begin{array}{l}\text { Letlhodi, cowpea, or Bambara } \\
\text { ground nut }\end{array}$ \\
\hline $\begin{array}{l}\text { Dikgobe tsa satampa } \\
\text { (samp) (Fig. } 2 \text { f) }\end{array}$ & Samp & $\begin{array}{l}\text { Sugar beans, butter beans, } \\
\text { cowpeas }\end{array}$ \\
\hline
\end{tabular}

For dikgobe made with lechotlho or lebutho, both are required to be soaked for $30 \mathrm{~min}$ to an hour followed by cooking about an hour before adding pre-soaked legumes. Lechotlho and lebutho are hard to cook because they are par-boiled dried whole maize grains. Mmidi (maize grain) is cooked for a shorter time than lechotlho and lebutho because it is not par-boiled, and cooking time for dikgobe made with samp (Fig. 2b) is even shorter because maize is decorticated and cracked. Dikgobe is cooked until tender, and salt and edible oil can be added for taste. Dikgobe supply more nutrients like proteins, since it is a combination of beans and maize. Dikgobe tsa lechotlho is reported to cause constipation in some individuals. Dikgobe tsa satampa is said to cause heart burn and may also result in constipation and bloating in some individuals. Dikgobe is available throughout the year.

\section{Leowane}

Lengangale is cooked as described above and is mixed with pounded watermelon/melon seeds, cooked, and then served. Leowane is rich in oil from the seed and said it provide vitamins. Leowane is reported to cause nausea in some people and is available from March to May, also some indicated throughout the year. 


\section{Morogo wa dinawa le makgomane (bean leaves + makgomane)}

Makgomane and bean leaves are washed, when beans leaves are half cooked, makgomane is added. Optional to makgomane, fruits like khusubele and melon can be also used. The mixture is mixed with vegetables, and salt is added for taste and cooked for a while until a mushy consistency is achieved. The product is served with a starch source after cooling or it can be sun dried for storage.

\section{Indigenous beverages Mosukujwane tea}

Mosukujwane (Lippia javanica and Lippia scaberrima) leaves are harvested, air/sun dried for a day, boiled in a water for tea making, and sugar is added. The tea can be consumed with milk. Mosukujwane tea is said to heal the kidneys and is available from April to June.

\section{Bojalwa Jwa Setswana (traditional sorghum beer)}

Sorghum grain is cleaned and soaked in water for some minutes, water is decanted. The soaked grain is placed in a cool place for about 3 days for germination. The germinated grain is sun dried for about 2 days and milled to a make "momela" (malt). Cleaned ungerminated sorghum grain is milled to a flour and cooked in boiling water to make masokwane (adjunct) to a consistency of soft porridge (not thick), cooled, mixed with water, and put in a tank. Momela is then mixed with mosokwane and allowed to stay overnight in a tank to initiate fermentation. After fermentation, the mixture (masifa) is cooked (to gelatinize starches) for an hour and cooled to become "mogetlo." The cooking is similar to mash cooking in modern brewing. The mixture (mogetlo) is cooled and allowed to stand overnight to ferment more. The semi-fermented sorghum (mogetlo) is cooked in water to further boost fermentable substrates. Additional water and momela is mixed with mogetlo, left for a day in tank covered with lid to allow further fermentation. After full fermentation, the product is sieved to separate the liquid from solid residue (moroko or dintshe or spent). The residue can be used to cook porridge. The beverage is reported to heal asthma, lowers high blood pressure and relieves the mind. The product is reported to cause diarrhea in some people and if too much fermentation happened to cause headache. The beverage is available throughout the year.

\section{Bojalwa Jwa lla}

This is processed from germinated dried sorghum malt (momela), maize meal, and brown sugar; milk/madila may also be used. Addition of milk/madila may boost free amino nitrogen (FAN) requirements for yeast. Maize meal is cooked for about $30 \mathrm{~min}$ into soft porridge, mixed with milk, and allowed to stay for 3 to 5 days. Then, momela is added and the mixture is cooked for about $2 \mathrm{~h}$. After simmering, cooled and some momela and water are added, mixed, and allowed to ferment overnight; after then is ready. The beverage is available from January to March.

\section{Khadi (fermented alcoholic beverage)}

Khadi is processed from segwere (tuber) of "mogakangaga" (Kedrostis hirtella) plant and brown sugar. Segwere is sliced, washed, and mixed with cool water followed by addition of brown sugar. Mogwana fruits may be added as an inoculum, source of sugar, and flavor. The mixture is tightly closed in a container to ferment for about 2 days. When mogwana fruits are used, fermentation can take place only overnight. After fermentation, the mixture is sieved to remove segwere (what is left as spent) and the beverage is ready. The beverage is said to relieve the mind and gives energy. The product is not consumed by children and is available from November to January.

\section{Morula beer}

Fully ripe morula fruits are harvested, cleaned, washed, and cooked in a boiled water for easy release of juice/ pulp and cooled. The outer cover is peeled off, and the fruits are beaten/pound softly (to avoid seed breakage) to release more juice/pulp. The juice pulp is sieved to remove the seeds, mixed well with water to make it less viscous, and placed in a closed container in a cool place to ferment for 1 to 2 days; after then is ready. The beverage is said to be rich in vitamins and relieve the mind and body. The product is said to cause heart burn to some individuals and is available from November to February.

\section{Challenges indicated}

Shortage of rain fall and high temperatures were indicted limiting the availability of some plant foods to be scarce (Table 4). The cooking time for some grains (beans and maize) was said long consuming energy, making them expensive. Some indicated infestation by pests such as weevils and molds when not dried properly. For some, the preparation takes a long time, particularly traditional fermented beverages. Fermentation defects also cause unpleasant odor and smell, bitter taste, and mold growth into the product.

Concerning the culture of traditional foods/dishes and beverages. Majority of the respondents $96 \%$ and $92 \%$, respectively indicated that people in the village still eat traditional foods and drink traditional beverages. Also majority $88 \%$ and $92 \%$, respectively indicated there is still knowledge on their traditional foods/dishes and beverage culture. However, few have indicated that there 
Table 4 Challenges indicated concerning particular indigenous foods/dishes and beverages

\begin{tabular}{|c|c|c|c|c|c|c|c|c|c|c|c|c|c|c|c|c|c|c|c|c|c|}
\hline \multirow[t]{2}{*}{ Challenges } & \multicolumn{21}{|c|}{ Indigenous foods/dishes and beverages } \\
\hline & A & B & C & D & E & $\mathrm{F}$ & G & $\mathrm{H}$ & I & J & K & L & M & N & $\mathrm{O}$ & $P$ & Q & $\mathrm{R}$ & $S$ & $\mathrm{~T}$ & $\bar{U}$ \\
\hline Shortage due to high temperature and poor rainfall & & + & + & + & & & & + & & + & + & & + & + & + & & + & & & + & + \\
\hline Shortage of ingredients/expensive & + & & & & + & + & & & & & & + & & & & & & + & & & \\
\hline Not tasty as it used to be & & + & & & & & & & & & & & & & & & & & & & \\
\hline Infestation by pests & & + & & & & & & & & + & & & & & & & & & & & \\
\hline Infestation by pests such as weevils & & & + & & & + & & & & & & & & & & & & + & & & \\
\hline Long-time to cook, shortage of fire wood, consume energy & & & + & + & + & & & & + & & & + & & & & & & & & & \\
\hline Infestation by mold & & & + & & & & & & & & & & + & & & + & & & & & \\
\hline Some people totally do not enjoy it & & & & & & & & + & & & & & & & & & & & & & \\
\hline Takes long time to prepare/long process/too much work & & & & & & & & & & & + & + & + & & & & & + & & & + \\
\hline Fermentation can be a problem in cool weather & & & & & & & & & & & & & & & & & & + & & & \\
\hline $\begin{array}{l}\text { Prolonged fermentation cause an unpleasant odor, smell and } \\
\text { bitter taste, moldy }\end{array}$ & & & & & & & & & & & & & & & & & & & + & & \\
\hline
\end{tabular}

A Leowane, B Makgomane, $C$ beans, D Kabu/maize, $E$ Lechotlho, $F$ Sorghum "mosokwane," G Leswabi, $H$ Lengangale, $I$ Lebutho, $J$ Letlhodi, $K$ Leowane, $L$ Dikgobe, $M$ Morogo wa Dinawa, $N$ Bogobe Jwa Lerotse, $O$ Legodu, $P$ Bogobe Jwa Ting, $Q$ Khadi, $R$ Traditional sorghum beer, $S$ Morula beer, $T$ Mosukujwane tea, $U$ Bojolwa Jwa lla

is lack of information, too much ignorance of the new generation about traditional foods and beverages, and too much importation and preference for foreign foods and beverages as challenges. Beverages like khadi are not produced like before, so there is a limitation for new generation to learn about them.

\section{Conclusions}

The plant-based traditional foods/dishes and beverages of Ramotswa village, Botswana, were investigated. The study generated 50 wild edible plants. The diversity of wild edible plants used shed light on their high potential for diet diversification and for food and nutrition security. Most of the edible plants are whole grain/seed/nut, fruits, leaves, tuber/roots, and some are fermented. Such diets are in line with the Lancet Commissions review on sustainable food systems. However, the communities have worries that the young generation has limited knowledge and skills to acquire and process them. For those nutrient and bioactive compound data are not investigated, this study provides baseline information for further studies.

\section{Acknowledgements}

Ramotswa village Paramount Chief and deputy Chiefs for their permit, study participants from Ramotswa village for sharing their knowledge, Shirley Ralenyena for serving as an enumerator, and Gombalume Tsaone and Lekaunyane Dimpho for serving as rapporteurs on FGD are acknowledged.

\section{Authors' contributions}

GB led the research, drafted and edited the manuscript (MS) along with RKL. Photographs of foods/dishes were produced by RKL. NT conducted FGD. MM served as co-team leader and participated in FGD. GDH, ES, and SM edited the MS. SM provided the scientific names. All authors, contributed as member of the research team, read and approved the MS.

\section{Funding}

Funding was provided by the RTD \&TC of BUAN.
Availability of data and materials

Not applicable.

\section{Competing interests}

The authors declare that they have no competing interests.

\section{Author details}

'Department of Food Science and Technology, BUAN, P. Bag 0027, Gaborone, Botswana. ${ }^{2}$ Department of Agricultural Extension and

Development, BUAN, P. Bag 0027, Gaborone, Botswana. ${ }^{3}$ Department of Biological Sciences, BUAN, P. Bag 0027, Gaborone, Botswana. ${ }^{4}$ Department of Biometry and Mathematics, BUAN, P. Bag 0027, Gaborone, Botswana.

Received: 2 October 2019 Accepted: 19 December 2019

Published online: 06 January 2020

References

1. Trichopoulou A, Vasilopoulou E, Georga K, Soukara S, Dilis V. Traditional foods: why and how to sustain them. Trends Food Sci Technol. 2006;17: 498-504.

2. Sofi F, Macchi C, Abbate R, Gensini GF, Casini A. Mediterranean diet and health. BioFactors. 2013;39(4):335-42.

3. Hernández-Ruiz A, García-Villanova B, Guerra-Hernández E, Amiano P, Sánchez M, Dorronsoro M, Molina-Montes E. Comparison of the dietary antioxidant profiles of 21 a priori defined Mediterranean diet indexes. $J$ Acad Nutr Diet. 2018;118(12):2254-68.

4. Willett W, Rockström J, Loken B, Springmann M, Lang T, Vermeulen S, et al. Food in the Anthropocene: the EAT-Lancet Commission on healthy diets from sustainable food systems. Lancet. 2019;393:447-92.

5. Kuhnlein HV. Food system sustainability for health and well-being of Indigenous Peoples. Public Health Nutr. 2014;18(13):2415-24.

6. FAO. High-Level Expert Seminar on Indigenous Food Systems Building on traditional knowledge to achieve Zero Hunger. Rome: FAO Headquarters; 2018.

7. Lindgren $E$, Harris F, Dangour AD, Gasparatos A, Hiramatsu M, Javadi F, Loken B, Murakami T, Scheelbeek P, Haines A. Sustainable food systems-a health perspective. Sustain Sci. 2019;13:1505-17.

8. Mabhaudhi T, Chibarabada TP, Chimonyo VGP, Murugani VG, Pereira LM, Sobratee N, Govender L, Slotow R, Modi AT. Mainstreaming underutilized indigenous and traditional crops into food systems: a South African perspective. Sustainability. 2019;11:172. https://doi.org/10.3390/su11010172.

9. Kwape LD. Diet and cardiovascular disease risk factors in Botswana. A PhD Thesis Submitted to Public Health Nutrition Research Group, Institute of Applied Health Sciences, University of Aberdeen, UK; 2012. 
10. Kasimba SN. Utilization of traditional and indigenous foods and potential contribution to consumers' nutrition and vendors' income in Botswana. A PhD Thesis Submitted to in Nutrition at the North-West University, Republic of South Africa; 2018.

11. Kasimba SN, Motswagole BS, Covic NM, Claasen N. Household access to traditional and indigenous foods positively associated with food security and dietary diversity in Botswana. Public Health Nutr. 2017;21(6):1200-8.

12. Denbow J, Thebe PC. Chapter 5. Cuisine and traditional dress. In: Falola T, editor. Culture and customs of Botswana. Westport: Greenwood Press; 2006. p. 107-33.

13. Harris JE, Gleason PM, Sheean PM, Boushey C, Beto JA, Bruemmer B. An introduction to qualitative research for food and nutrition professionals. J Am Diet Assoc. 2009;109:80-90.

14. McCune LM, Kuhnlein HV. Chapter 15. Assessments of indigenous peoples' traditional food and nutrition systems. In: Anderson EN, Pearsall D, Hunn E, Turner N, editors. Ethnobiology. New Jersey: Wiley; 2011. p. 249-66.

15. Mothanka DMT, Mothanka P, Selebatso T. Edible indigenous wild fruit plants of eastern Botswana. Int J Poult Sci. 2008;7(5):457-60.

16. Neudeck L, Avelino L, Bareetseng P, Ngwenya BN, Teketay D, Motsholapheko MR. The contribution of edible wild plants to food security, dietary diversity and income of households in Shorobe Village, Northern Botswana. Ethnobot Res Appl. 2012;10:449-62

17. Badimo D, Lepetu J, Teketay D. Utilization of edible wild plants and their contribution to household income in Gweta Village, central Botswana. Afr J Food Sci Technol. 2015;6(7):220-8.

18. Flyman MV, Afolayan AJ. A survey of plants used as wild vegetables in four districts of Botswana. Ecol Food Nutr. 2006;45(6):405-15. https://doi.org/10. 1080/03670240600985431.

19. Mothanka DM, Makhabu SW. Medicinal and edible wild fruit plants of Botswana as emerging new crop opportunities. J Med Plants Res. 2011; 5(10):1836-42.

20. Amarteifio JO, Mosase MO. The chemical composition of selected indigenous fruits of Botswana. J Appl Sci Environ Manage. 2006;10(2):43-7.

21. Phatlane M, Masehla MC. The effect of mixed and separate boiling extraction on the bioactivity of root extracts of Ziziphus mucronata, Prunus persica and Prunus armeniaca. S Afr J B. 2015;98. https://doi.org/10.1016/j. sajb.2015.03.157.

22. Chinsembu KC, Syakalima M, Semenya SS. Ethnomedicinal plants used by traditional healers in the management of HIV/AIDS opportunistic diseases in Lusaka, Zambia South. Afr J Bot. 2019;122:369-84.

23. Masondo NA, Stafford GI, Aremu AO, Makunga NP. Review: acetylcholinesterase inhibitors from southern African plants: an overview of ethnobotanical, pharmacological potential and phytochemical research including and beyond Alzheimer's disease treatment. S Afr J Bot. 2019;120:39-64.

24. Van Wyk BE. The potential of South African plants in the development of new food and beverage products. S Afr J Bot. 2011;77:857-68.

25. Mogale MMP, Raimondob DC, VanWyk BE. The ethnobotany of Central Sekhukhuneland, South Africa. S Afr J Bot. 2019;122:90-119.

26. Adebayo SA, Amoo SO. Review: South African botanical resources: a gold mine of natural pro-inflammatory enzyme inhibitors? S Afr J Bot. 2019;123:214-27.

27. Chivandi E, Cave E, Davidson BC, Erlwanger KH, Moyo D, Madziva MT. Suppression of Caco-2 and HEK-293 cell proliferation by Kigelia africana, Mimusops zeyheri and Ximenia caffra seed oils. In Vivo. 2012;26:99-106.

28. Gomes MN, Augustine TN, Moyoa D, Chivandi E. Differential response of breast cancer cell lines to Kigelia africana, Ximenia caffra and Mimusops zeyheri seed oils. S Afr J Bot. 2019;121:463-9.

29. Liu NQ, Van der Kooy F, Verpoorte R. Review Artemisia afra: a potential flagship for African medicinal plants? S Afr J Bot. 2009;75:185-95.

\section{Publisher's Note}

Springer Nature remains neutral with regard to jurisdictional claims in published maps and institutional affiliations.

Ready to submit your research? Choose BMC and benefit from:
- fast, convenient online submission
- thorough peer review by experienced researchers in your field
- rapid publication on acceptance
- support for research data, including large and complex data types
- gold Open Access which fosters wider collaboration and increased citations
- maximum visibility for your research: over 100M website views per year
At BMC, research is always in progress.
Learn more biomedcentral.com/submissions

